\title{
Hypno-sedative activity of Gymnema sylvestre extract in sodium barbiturate - induced hypnosis in Rattus novergicus
}

\author{
Omale James, Menegbe Nasara Awam, Ojogbane Eleojo \\ Department of Biochemistry, Faculty of Natural Sciences, Kogi State University, Anyigba, Nigeria
}

Email address:

James.omale123@yahoo.com (O. James)

\section{To cite this article:}

Omale James, Menegbe Nasara Awam, Ojogbane Eleojo. Hypno-Sedative Activity of Gymnema sylvestre Extract in Sodium Barbiturate Induced Hypnosis in Rattus novergicus. Advances in Biochemistry. Vol. 2, No. 5, 2014, pp. 60-64. doi: 10.11648/j.ab.20140205.11

\begin{abstract}
Gymnema sylvestre is a rare herb with significant medical attributes and ethno-botanical uses. Insomnia is one of the most common sleep disorders around the world. In this study, the effect of the aqueous extracts of this plant was investigated for its hypno-sedative effect in rats as well as acute toxicity. Leaf, stem and flowers of G.sylvestre have several therapeutic applications in folk medicine in curing or managing of a wide range of diseases including insomnia. Sleep was induced using sodium barbiturate in albino rats. Rats of either sex weighing between 100-115g were grouped into five groups A,B,C,D and E of four animals each. Group A was the negative control and received only water, groups B the positive control received $10 \mathrm{mg} / \mathrm{kg}$ b.w of diazepam .Groups C,D and $\mathrm{E}$ were administered 150,700 and $1500 \mathrm{mg} / \mathrm{kg} \mathrm{b} . \mathrm{w}$ of extracts respectively, each of the rat was placed in individual cage and observed over a period of 24 hours at 6 hours interval .The aqueous extracts produced significant sedative effect at the dose of $150 \mathrm{mg} / \mathrm{kg} \mathrm{b} . \mathrm{w}$ and was more effective than diazepam. The extracts at the doses of 150 and $700 \mathrm{mg} / \mathrm{kg}$ b.w exhibited hypno-sedative activity comparable to the reference drug. The stem extract at $1500 \mathrm{mg} / \mathrm{kg}$ produced no sedative effect. No toxicity signs were observed following acute toxicity evaluation. The extracts showed hypno-sedative activity at lower doses of $150 \mathrm{mg} / \mathrm{kg} \mathrm{b} . \mathrm{w}$ in this increasing order, stem $\rightarrow$ leaf $\rightarrow$ flower. In conclusion, these results suggest that the aqueous extract of G. sylvestre is relatively non-toxic and possess potent sedative and hypnotic effects which could support its therapeutic use for insomnia in folk medicine.
\end{abstract}

Keywords: Hypno-Sedative, Sodium Barbiturate, Gymnema sylvestre, Rattus novergicus

\section{Introduction}

Nigeria is most fortunate to have varied climate that almost any medicinal plant can grow. A medicinal plant is any plant which in which one or more of its organs, contain substance that can be used for therapeutic purpose or which are precursor for chemo-pharmaceutical semi-synthesis. Healing with medicinal plants is as old as mankind. The use of medicinal plants as fundamental component of the African traditional health care system is perhaps the oldest and most assorted of all the therapeutic systems.

Insomnia is defined as persistent difficulty in falling or staying asleep that affects function and can induce significant psychological and physical disorder. Sedatives are drugs that decrease activity and have a calming, relaxing effect. At higher dose, sedatives usually cause sleep. Drugs used mainly to cause sleep are called hypnotics. The difference between sedative and hypnotics then, is usually the amount of the dose; lower doses have a calming effect and higher doses cause sleep (Huang et al., 2007)

Insomnia is a frequent problem that affects people of all the ages around the world. It is a prevalent and potentially serious condition that adversely affects the diurnal functioning, health status and life quality of people of all ages (Edinger and Means,2005). Stress, anxiety and depression could trigger insomnia. As well as cough, chronic pain, apnea, circadian rhythm disorders and neural diseases are conditions also associated with insomnia (Harvey,2001).

Insomnia is treated pharmacologically and nonpharmacologically or with a combination of both (Benca, 2005). Benzodiazepine, zolpidem, zopiclone, zaleplon have been used for the treatment of insomnia (Gottesmann, 2002). Relaxation, stimulus control, sleep restriction and sleep hygiene are common behavioral therapeutics for insomnia (Nan et al., 2005).

Medicinal plants constitute another option to treat insomnia. Around the world have been used several plants like sleep inducers such as valerian, passion flower, Melissa, Hops and Kava-Kava (Banned) (Wheatley, 2005). 
Recent studies have shown that herbal drugs exert good sedative and hypnotic effect on central nervous system (Huang et al., 2007; Herrera-Ruiz et al., 2007; Perez-ortega et al., 2008).

Gymnema sylvestre is a perennial wood climber which belong to the family Asclepiadaceae or the milk weed family (Kanetka et al.,2007). G .sylvestre has several medicinal attributes. It is presently used traditionally as tea bags, beverages and confectionaries and it is also a good source of bioactive substances (Ch et al., 2012).

Traditionally the leaves of $G$. sylvestre were used for the treatment of diabetes and other disorders, while the flowers and bark are given in disease related to phlegun (Kirtika and Basu, 1975). Reports in the ancient literatures suggested that the plant has multiple medicinal applications namely, antipyretic cardio tonic, liver tonic, digestive diuretic, cough dyspepsia laxative, stimulant etc the root bark is useful as an enemetic, expectorant and analgesic for body ache and root juice in the treatment of snake bite (Anis et al., 2000). The plant also exhibits medicinal importance in the treatment of constipation, cardiopathy asthma, bronchitis, conjuctivits and vesical calculi etc (Anis et al.,2000).

The leaves of $G$. sylvestre contain triterpene saponins belonging to oleane and damarane classes. The major constituent like gymnemic acids and gymnema saponins are members of oleane type of saponins while gymnemasides are damarane saponins (Foster, 20002). There have been speculations in ethno- medicine that Gymnema sylvestre leaf extract cause sedation in diabetic patients. Sedation is the reduction of irritability or agitation by the means of administration of sedative drugs. Hypno-sedation reduces that need for general anesthesia (Brown et al., 2010).

The aim of this study was to evaluate the sedative and hypnotic activities of Gymnema sylvestre aqueous extracts in sodium barbiturate induced hypnosis in Rattus novergicus, and to therefore, determine the scientific basis for its use in traditional medicine in the management of central nervous system disorders.

\section{Materials and Methods}

Plant material- The leaf, stem and flower of Gymnema sylvestre were collected based on ethno pharmacological information from the villagers in Ajokuta Local Government Area of Kogi State, Nigeria. The plant had already been authenticated by Dr, William D. Hawthrone, a James Martin Research fellow, Plants for the $21^{\text {st }}$ century, Department of plant sciences, University of Oxford. The collected plant parts were rinsed with clean water to remove dirt. The leaves and flowers were plucked from the stem and were separately spread and air-dried under shade at room temperature for three (3) weeks.

\subsection{Preparation of Plant Extracts}

The air-dried leaves and flowers were pulverized into powder using an electric blender while the stem was first pounded into semi-powder with mortar and pestle, which was further pulverized into fine powder utilizing mechanical grinder. Cold extraction method was used to obtain aqueous extracts of the samples. Portions (197.7g) of leaf, $271.15 \mathrm{~g}$ of powdered stem and $103.89 \mathrm{~g}$ of powdered flower were soaked in different containers with $2000 \mathrm{ml}$ of distilled water each. They were properly stirred and left for four (4) days with continuous stirring each day. The mixtures were then filtered using the high pressure vacuum pump machine. The filtrates in beakers were concentrated by evaporation at $60^{\circ} \mathrm{C}$ to dryness in a water bath.

\subsection{Animals}

The experimental animal used was albino rats (Rattus novergicus) of either sex weighing between 100-115g. They were obtained from a breeder at Kogi State University Staff Quarters, and housed in wired cages in the animal house of the Department of Biochemistry, Faculty of Natural Sciences Kogi State University, Anyigba, Nigeria and were acclimatized for two weeks prior to the commencement of the experiments. The animals were housed under standard laboratory conditions, light and dark cycles of $12 \mathrm{~h}$, and were provided with standard rodent pellet diet and water ad libitum. The animals were categorized into control and experimental groups. Group A was the negative control and received only water while group B was the positive control which received $10 \mathrm{mg} / \mathrm{kg}$ of diazepam. Groups C,D, and E were administered 150,700 and $1500 \mathrm{mg} / \mathrm{kg}$ b.w of extracts respectively. There were four rats per group.

Appropriate authority has consented to the use of these animals in the Department of Biochemistry for experimental purpose.

\subsection{Drugs}

All drugs were freshly prepared on the day of experiments. Diazepam was obtain from Kuzak Pharmacy store in Anyigba, Kogi State, Nigeria and was of the Pfizer product. Sodium barbiturate was obtained from British Drug House. The other reagents were of analytical grade.

\subsection{Acute Toxicity Study}

The median lethal dose $\left(\mathrm{LD}_{50}\right)$ values were determined as described by Litchfield and Wilcoxon (1949). The acute toxicity test was carried out on the rats to evaluate any possible toxicity. Seven groups of rats numbering four rats per group of either sex were treated with different doses $(150,700,15002000,2500,5000$ and 6,000mg/kg p.o) . After a single dose administration the rats were placed in individual cages and were observed for 24hours and 6 hour time interval to detect any eventual side effects. The method estimated the dose of the extract that would kill $50 \%$ of a reduced sample of animal by a given route.

In the first phase, the extract was given to four rats per group at the doses of $150,700,1500$, and $2000 \mathrm{mg} / \mathrm{kg}$; when no mortality was observed, the doses were increased to 2,500 , 5000 and $6,000 \mathrm{mg} / \mathrm{kg}$. Rats were kept under further observation for 14 days to register further possible mortality. 


\subsection{Hypno-Sedative Activity Study}

Rats of either sex were acclimatized for two weeks. The animals were divided into five groups of four rats each.

Groups A. Treated with distilled water ( $1 \mathrm{ml} / \mathrm{kg} \mathrm{p.o)}$ which served as control

Group B. Served as standard (treated with $10 \mathrm{mg} / \mathrm{kg}$ b.w p.o diazepam)

Group C. Treated with $150 \mathrm{mg} / \mathrm{kg}$ b.w p.o extract.

Group D. Treated with $700 \mathrm{mg} / \mathrm{kg}$ b.w p.o extract.

Group E. Treated with extract at $1500 \mathrm{mg} / \mathrm{kg}$ b.w p.o

After 60 minutes of the previous treatments, $50 \mathrm{mg} / \mathrm{kg}$ of sodium barbiturate was administered to all the animals to induce sleep. Each animal was observed for onset and duration of sleep. The duration of sleep or hypnosis was considered the loss of postural reflex. The effect was recorded for disappearance (on set of sleep) and reappearance (duration) of the righting reflex. Hypnotic sleeping time was considered to be the time interval between disappearance and reappearance of the righting reflex (Herrera-Ruiz et al.,2007).

\section{Statistical Analysis}

The statistical analysis was done using analysis of variance (ANOVA) and students t-test was carried out on data and $(p<0.05)$ was considered significant. The data are expressed as mean \pm S.D

\section{Results /Discussion}

\subsection{Acute Toxicity of G. sylvestre Aqueous Extracts}

Following oral administration of the aqueous extracts of $G$. sylvestre extracts at the doses of 150, 700, 1500, 2000, 2500, 5000 and $6000 \mathrm{mg} / \mathrm{kg}$ P.O. There was no toxicity sign observed and no significant changes in the body weight between the control and treated group were observed at these doses. This result clearly indicates that the $\mathrm{LD}_{50}$ was higher than $6000 \mathrm{mg} / \mathrm{kg}$. This is an indication of relative safety.

\subsection{Hypno-Sedative Activity of the Extracts}

Table 1. Effect of the aqueous leaf extract of G. sylvestre on the onset and duration of sleep in sodium barbiturate treated rats.

\begin{tabular}{llll}
\hline Group & Treatment/ dose $(\mathbf{M g} / \mathbf{k g})$ & Sleep latency (minutes) & Sleep time (minutes) \\
\hline A & Water $(\mathrm{lml} / \mathrm{kg})$ & $34.50 \pm 0.58$ & $66.00 \pm 1.16$ \\
B & Diazepam $(10 \mathrm{mg} / \mathrm{kg})$ & $20.00 \pm 0.00^{\mathrm{a}}$ & $72.50 \pm 2.86$ \\
C & $150 \mathrm{mg} / \mathrm{kg}$ extract & $15.00 \pm 0.50^{\mathrm{b}}$ & $87.50 \pm 8.66$ \\
D & $700 \mathrm{mg} / \mathrm{kg}$ extract & $13.50 \pm 1.00^{\mathrm{c}}$ & $72.25 \pm 4.50 \pm 0.58$ \\
E & $1500 \mathrm{mg} / \mathrm{kg}$ extract & $3.75 \pm 0.50^{\mathrm{d}}$ & $72.50 \pm 8.66^{\mathrm{b}}$ \\
\hline
\end{tabular}

Values with different superscript in a column are statistically significant $(\mathrm{p}<0.05)$. Values are mean \pm S.D of four replications.

Table 2. Effect of the aqueous stem extract of $G$. sylvestre on the onset and duration of sleep in sodium barbiturate treated rats.

\begin{tabular}{|c|c|c|c|c|}
\hline Group & Treatment/ dose ( Mg/kg) & Sleep latency (minutes) & Sleep time (minutes) & Duration (minutes) \\
\hline $\mathrm{A}$ & water $(1 \mathrm{mg} / \mathrm{kg})$ & $34.50 \pm 0.58$ & $66.00 \pm 1.16$ & $31.50 \pm 0.58$ \\
\hline B & Diazepam $(10 \mathrm{mg} / \mathrm{kg})$ & $20.00 \pm 0.00^{\mathrm{a}}$ & $72.50 \pm 2.86$ & $52.00 \pm 2.89^{\mathrm{a}}$ \\
\hline $\mathrm{C}$ & $150 \mathrm{mg} / \mathrm{kg}$ extract & $49.50 \pm 1.73^{b}$ & $14.50 \pm 4.00$ & $35.50 \pm 2.27^{\mathrm{b}}$ \\
\hline $\mathrm{D}$ & $700 \mathrm{mg} / \mathrm{kg}$ extract & $47.00 \pm 1.16^{\mathrm{c}}$ & $6.25 \pm 1.50$ & $40.75 \pm 0.34^{\mathrm{c}}$ \\
\hline E & $1500 \mathrm{mg} / \mathrm{kg}$ extract & $0.00 \pm 0.00^{d}$ & $0.00 \pm 0.00$ & $0.00 \pm 0.00^{\mathrm{d}}$ \\
\hline
\end{tabular}

Values with different superscript in a column are statistically significant ( $p>0.05)$. Values are mean \pm S. D of four replications.

Table 3. Effect of the aqueous flower extract of G. Sylvestre on the onset and duration of sleep in sodium barbiturate treated rats

\begin{tabular}{llll}
\hline Group & Treatment/ dose $(\mathbf{M g} / \mathbf{k g})$ & Sleep latency (minutes) & Sleep time (minutes) \\
\hline A & Water $(1 \mathrm{~m} / \mathrm{kg})$ & $34.50 \pm 0.58$ & $66.00 \pm 1.16$ \\
B & Diazepam $(10 \mathrm{mg} / \mathrm{kg})$ & $20.00 \pm 00^{\mathrm{a}}$ & $72.50 \pm 2.86$ \\
C & $150 \mathrm{mg} / \mathrm{kg}$ extract & $14.75 \pm 0.50^{\mathrm{b}}$ & $217.50 \pm 2.70$ \\
D & $700 \mathrm{mg} / \mathrm{kg}$ extract & $13.75 \pm 0.89^{\mathrm{c}}$ & $193.50 \pm 4.90$ \\
E & $1500 \mathrm{mg} / \mathrm{kg}$ extract & $0.50 \pm 0.58^{\mathrm{d}}$ & $171.00 \pm 13.86$ \\
\hline
\end{tabular}

Values are mean $\pm S . D, n=4$.Values with different superscript in a column are statistically significant $(\mathrm{p}<0.05)$.

Table 1, showed significant $(\mathrm{p}<0.05)$ dose- dependent decrease in the latency of sleep time of animals which received the extract.

A difference of $19.50,21.00$ and 30.75 minutes in groups $\mathrm{C}, \mathrm{D}$ and $\mathrm{E}$ from the control value of $34.50 \pm 0.58$ minutes in group A. Animals in group B which received diazepam, a standard drug gave a difference of 14.50minutes in latency of sleep time from the control value. There was also dose- dependent significant $(\mathrm{p}<0.05)$ decrease in the duration of sleep time in animals that were administered the extract in groups $\mathrm{C}, \mathrm{D}$ and $\mathrm{E}$, the duration of sleep time were $72.50 \pm$ 8.66, 58.75 \pm 3.50 and $56.00 \pm 7.00$ respectively. Animals which were administered diazepam had duration of sleep time of $52.00 \pm 2.89$ while animals in group A had duration of sleep time of $31.50 \pm 0.58$ respectively.

In table 2 , there was a dose - dependent significant $(\mathrm{P}<$ 
0.05) decrease in the latency of sleep time among animal in group $\mathrm{C}, \mathrm{D}$ and $\mathrm{E}$ which received the stem extract at doses of 150,700 and $1500 \mathrm{mg} / \mathrm{kg}$ b.w. the latency of sleep time was $49.50 \pm 1.73,47.00 \pm 1.16$ and $0.00 \pm 0.00$ minutes respectively. The treatment caused a non-significant $(p>0.05)$ effect in the duration of sleep time of $35.50 \pm 2.27$ minutes in group $\mathrm{C}$ and $40.75 \pm 0.34$ minutes in group D. In group $\mathrm{E}$ the animals were completely awake.

In table 3 , the latency of sleep time decreased in a significant $(\mathrm{p}<0.05)$ dose -dependent manner of animals in group $\mathrm{C}, \mathrm{D}$ and $\mathrm{E}$ which were administered doses of 150, 700 and $1500 \mathrm{mg} / \mathrm{kg}$ of the extract, the latency of sleep times were (14.75 $\pm 0.05,13.75 \pm 0.89$, and $0.05 \pm 0.58$ minutes) respectively. This effect compares with animals in group B which received diazepam and had latency of sleep time of $20.00 \pm 0.00$ minutes. The treatment had significant $(p<0.05)$ dose - dependent decrease in the duration of sleep time in group $\mathrm{C}, \mathrm{D}$ and $\mathrm{E}$. The duration of sleep time were $202.75 \pm 2.65, \quad 179.75 \pm 4.81$ and $170.5 \pm 13.28$ minutes respectively.

Up to a dose of $6000 \mathrm{mg} / \mathrm{kg}$ b.w administered, the animal showed no signs of toxicity, indicating that the extracts used were relatively safe and caused no observable toxic effect. In this investigation, we observed the sedative and hypnotic properties of aqueous extract from $G$. sylvestre in rats. Diazepam is central nervous system depressant used in the management of sleep disorders such as insomnia; these compound have a binding site on GABA receptor type Aionophore complex $\left(\mathrm{GABA}_{\mathrm{A}}\right)$ (Huang et al.,2007; HerreraRuiz et al., 2007).

It decreases activity, moderates excitement, and calms the recipient. Substances like diazepam (which has been selected as the standard reference drug in this investigation) reduce latency or onset of and increase duration of barbiturate induced sleep and reduce activity possessing potentials as sedative (File and Wardill,1975; Roy-Byrne,2005).

The latency of sleep time significantly $(\mathrm{P}<0.05)$ decreased with increase in dosage of the extracts, this may be attributed to an inhibition of the barbiturate metabolism or to an action in the regulation of sleep extracts at lower dose. $(150 \mathrm{mg} / \mathrm{kg})$ caused hypno-sedation, it becomes imperative to try this experiment with doses lower than $150 \mathrm{mg} / \mathrm{kg}$. However, high dose of the leaf extract $(1500 \mathrm{mg} / \mathrm{kg})$ exhibited nonsignificant $(p>0.05)$ sedative effect comparable to diazepam (table 1).

The anti-hypno-sedative effect of the stem extract at $1500 \mathrm{mg} / \mathrm{kg}$ b.w is evident by the 24hours lost of sleep (insomnia) by animals in group E (Table 2). The latency of sleep time significantly $(\mathrm{P}<0.05)$ decreased with increase in the doses of extract, however, the duration of sleep time were more prolonged in animals which received the flower extract (Table 3). All sedative effect peaks at $150 \mathrm{mg} / \mathrm{kg}$ b.w. Observation from this study showed that $G$. sylvestre extracts could posses both hypno-sedative and anti-hyno-sedative properties. The order of increasing sedative activity of the plant parts is stem $\rightarrow$ Leaf $\rightarrow$ flower. The speculation of the ethno-medical practitioners on the sedative properties of $G$. sylvestre extract might not be wild.

Further pharmacological analysis of the extracts will be conducted to isolate and characterize the active principles responsible for the sedative and hypnotic effect.

\section{Conclusion}

In conclusion, acute study showed that the plant parts are relatively non-toxic. Oral administration of aqueous extract of G. sylvestre induces sedative effects, supporting its use in folk medicine. Since the $\mathrm{LD}_{50}$ values of the extract was above $6000 \mathrm{mg} / \mathrm{kg}$ b.w for oral administration as determined following the method described by Litchfield and wilcoxon 1949; these results indicate a remote risk of acute toxicity and good tolerance of these extracts in traditional medicine.

In summary this present work represents that aqueous extract of $G$. sylvestre have obvious sedative and hypnotic activity and at higher doses can keep organism awake. The presented data provides pharmacological evidence for its therapeutic use on insomnia and could be added to the list of Nigeria medicinal plants for further screening.

\section{Acknowledgement}

The authors are grateful to the academic supporting staff of the Department of Biochemistry laboratory, Kogi State University, Anyigba, Nigeria for their technical assistance in this work.

\section{References}

[1] Anis, M., Sharma, M.P., and lqbal M (2000) .Herbal ethno medicine of the Gwalior Forest division in Madhya Predesh India. Pharmaceutical Biology. 38.(4).241-253.

[2] Benca, R. (2005) Diagnosis and treatment of chronic insomnia: A review. Psychiatric services. 56: 332-342.

[3] Ch, B., Rao, K., Gandi, S., and Giri, A(2012). Abiotic elicitation of gymnemic acid in the suspension cultures of Gymnema sylvestre . World Journal of Microbiology and Biotechnology. 28(2):741-747.

[4] Edinger, J., Means, M (2005) .Cognitive behavioral therapy for primary insomnia. Clinical Psychology Review. 256:539558 .

[5] Gottesmann, C (2002) .GABA mechanisms and sleep. Neuroscience 111:321-239.

[6] File, S.E and Wardill , A. G (1975). Validity of head dipping as a measure of exploration in modified hole board. Pschopharmacologia 44(1): 53- 59.

[7] Foster, S (2002) .Gymnema sylvestre in alternative medicine review monograph. Thorne Research inc. 205-207.

[8] Herrera-Ruiz, M., Gutierrez, C., Enrique Jimenez-ferrer, J., Tortoriello, J., Morion, G and Leon, I (2007) .Central nervous system depressant activity of an ethyl acetate extract from Ipomoea stans roots. Journal of ethno- pharmacology .112 (2) 243-247. 
[9] Harvey A. (2001). Insomnia: symptom or diagnosis? Clinical Psychology Review 21:1037-1059.

[10] Huang, F., Xiong, Y., Xu, L., Ma, S,and Dou, C. (2007). Sedative and hypnotic activities of the ethanol fraction from Fructus schisandrae in mice and rats, Journal of ethnophamacology 110 (3): 471-475.

[11] Kanetkar, P., Singhal R, and Kamat, M (2007) Gymnema sylvestre: a memoir' Journal of Clinical Biochemistry and Nutrition 641(2): 77-81.

[12] Kirtika, K.,R., Basu, B.D. (1975) Indian medicinal plants, vol.3 Periodical experts, Delhi india.

[13] Litchfield, J.T and Wilcoxon, F (1949). A simplified method of evaluating dose effect experiments. Journal of Pharmacology and Experimental Therapeutics 96:99-113.

[14] Nan, S.D., Mcrac, C.S., Cook, K.G, Lichstein, K.L. (2005). Treatment of insomnia in older adults. Clinical psychology review ,25:645-672.
[15] Perez- Ortega, G., Guevara-Fefer, P., Chavez,M (2008) Sedative anxiolytic efficacy of Tilia americana var. mexicana inflorescences used traditionally by communities of state of Michoacan, mexizo. Journal of ethno pharmacology. 16 (3) 461-468.

[16] Roy-Byrne , P.P( 2005). The GABA- benzodiazepine receptor complex : Structure, function, and role in anxiety . Journal of Clinical Psychiatry 66(2): 14 -20.

[17] Wheatley, D. (2005) Medicinal plants for insomnia: A review of their pharmacology, efficacy and tolerability. Journal of Psychopharmacology. 19:414-421.

[18] Brown EN, Lydic R, Schiff ND (2010). General anesthesia, sleep and coma. N Engl J Med. 363(27):2638-50. 